\title{
ECONOMICS
}

\section{LOCAL GOVERNMENT DEBT AND ECONOMIC GROWTH IN CHINA}

by

Yanrui Wu

Business School

University of Western Australia 


\author{
Yanrui $\mathrm{Wu}$ \\ Professor, Business School \\ University of Western Australia \\ (yanrui.wu@uwa.edu.au)
}

DISCUSSION PAPER 15.11

\begin{abstract}
:
China's local government debt (LGD) has recently become the focus of economic policy debates. However, information about LGD and its impact on economic growth in the Chinese economy is scarce. This paper attempts to present an empirical investigation of the impact of China's LGD on economic growth. It is probably the first of its kind to focus on China and thus contributes to the general literature on the relationship between government debt and economic growth. The paper first provides an assessment of LGD in China's regional economies, using recently released auditing statistics and other available secondary information. It then applies conventional growth analysis methods to examine the impact of LGD on regional growth in China. Various scenario and sensitivity analyses are also conducted, to accommodate the inadequacy and potentially poor quality of debt statistics.
\end{abstract}

Key Words: Local government debt, regional growth, China

JEL Codes: O11, O53, H74

Acknowledgements: The author thanks Loren Brandt, Iikka Korhonen, Laura Solanko and participants of the Industrial Upgrading and Urbanization conference (Stockholm School of Economics) and seminars at BOFIT, Hefei University of Technology, Jiangxi University of Finance and Economics and University of Macau for their helpful comments and suggestions. Work on this paper benefited from generous financial support by the Bank of Finland, Hefei University of Technology, the University of Macau and Jinan University (Fundamental Research Funds for the Central Universities). 


\section{Introduction}

Since the onset of the global financial crisis in 2007, public or government debt, particularly local government debt (LGD), has attracted considerable attention worldwide. ${ }^{1}$ The debt crisis of the City of Detroit has generated considerable anxiety among policy makers. China is no exception. The country's National Audit Office (NAO) conducted nation-wide auditing of government debt in the regions in 2011 and 2013 (NAO 2011, 2013). The 2013 audit results show that China's total government debt-to-GDP ratio (hereafter debt-GDP ratio) in 2012 was about 39\%, which is below the $60 \%$ critical level of the euro convergence criteria. ${ }^{2}$ The Chinese government's debt-alarm bells seem not to be ringing at the present time.

Economists have long debated the role of government debt in economic development (Krueger 1987, Krugman 1988). In general, the theoretical literature finds a negative effect of debt on economic growth (Modigliani 1961, Sait-Paul 1992, Corsetti et al. 2010). Early empirical studies mainly focused on the role of external debt in developing economies. For example, Smyth and Hsing (1995) found a non-linear effect of external debt on growth and two IMF working papers found a negative effect of external debt on growth once the debt-GDP ratio reached a certain level such as 20-40\% (Pattillo et al. 2002, Clements et al. 2003). The debate has recently been reignited by the work of Reinhart and Rogoff (2010) who argued that economic growth disappears as government debt-GDP ratio reaches 90 per cent or the so-called threshold debt level in selected OECD economies. Their finding has been challenged and so has stimulated a series of studies in this area (Reinhart et al. 2012, Baum et

\footnotetext{
1 As for media coverage, examples include the Economist (2009) and Foreign Affairs (Rajan 2012).

2 The euro convergence criteria are also known as the Maastricht criteria (ECB 2014).
} 
al. 2013). ${ }^{3}$ Some authors pointed out errors in the Reinhart-Rogoff estimation methodology (Afonso and Jalles 2013, Herndon et al. 2014). Others developed econometric models to test the existence of a threshold debt level (Egert 2013, Pescatori et al. 2014).

Nonetheless, there is generally a dearth of empirical investigations of the role of government debt in economic growth in China, not to mention the LGD. Fan and Lv (2012) is probably the first published paper to provide a review of China's government debt situation. The authors concluded with an optimistic view of China's government debt, but they did call for further reform of China’s fiscal and financial system over the long run. A slightly related paper by Tsui (2011) presented a more pessimistic picture of China’s LGD. The author linked LGD with investment in large infrastructure projects in China and reckoned that the country's rapid expansion in infrastructure development engenders risks and hence is not sustainable.

This paper aims to extend the literature by presenting an empirical examination of China's LGD and its impact on economic development. It is probably the first empirical paper on this topic (the papers by Fan and Lv (2012) and by Tsui (2011) are descriptive). The paper proceeds with some stylized facts about government debt in China in Section 2. This is followed by a description of the analytical techniques and data issues in Section 3 and a discussion of the empirical findings in Section 4. Some further analyses are explored in Section 5, and concluding remarks are presented in Section 6.

\section{Stylized Facts about Government Debt in China}

Government debt in the People's Republic of China has emerged since the introduction of

\footnotetext{
${ }^{3}$ For a survey of the literature, see Panizza and Presbitero (2013).
} 
economic reforms in the late 1970s. After decades of isolation from the rest of the world, the country’s central government took foreign loans of about 3.53 billion Yuan (about US\$2.2 billion) in 1979 according to the Editorial Board (2013). Since then, foreign borrowing has increased steadily and peaked in 1993 at 35.8 billion Yuan (about US\$6.1 billion). In 1981 Chinese governments started borrowing from the domestic public, and government debt has subsequently increased rapidly. This is in line with the global trend in government debt. Some authors blame financial globalization and increasing inequality for the rise of government debt (Azzimonti et al. 2014). These factors seem to fit well with the Chinese case too. China's local governments are generally prohibited from borrowing from the public directly. However there are exceptions. For example, in 1979 eight counties or districts borrowed from the public (NAO 2011). These was possible only with permission from the central government. It is reported that over time more local governments are receiving permission to increase their debts. Though local governments cannot borrow from the public directly, they can borrow through their agencies, such as state-owned enterprises (SOEs) and government controlled financial institutions. The consequence of such practice is an escalation of government debt in the regions, with little transparency. For this reason, the central government conducted two nation-wide audits of government debt, in 2011 and 2013. To improve transparency, in early 2014, ten provinces and municipalities (Beijing, Jiangsu, Shanghai, Shenzhen, Guangdong, Zhejiang, Jiangxi, Shandong, Ningxia and Qingdao) received approval from the Ministry of Finance to issue local government bonds directly. This represents a major change in public finance and governance and may have implications for regional economic development in China.

Having the largest foreign reserve holdings, China's external debt can be described as 
modest, and it has seen a steadily declining debt-GDP ratio in recent years (Figure 1). However the domestic debt of both the central and local governments has been on the rise. In 2012, China's total government debt was almost equally shared between the central and local governments. The central government debt (CGD) as a proportion of GDP peaked in 2007 and has remained stable at around 16 per cent in the past decade (Figure 1). The ratio of LGD to gross regional product (debt-GRP ratio) has remained on an upward trend, particularly in recent years. On average, the debt-GRP ratio exceeded the central government's debt ratio in 2011 and 2012. This was probably one of the reasons for the nation-wide audit of government debt in 2011 and 2013. The debt-GRP ratio, however, varies considerably across the regions, ranging from 7.9 per cent in Shandong to 48.2 per cent in Guizhou in 2012 (Figure 2).

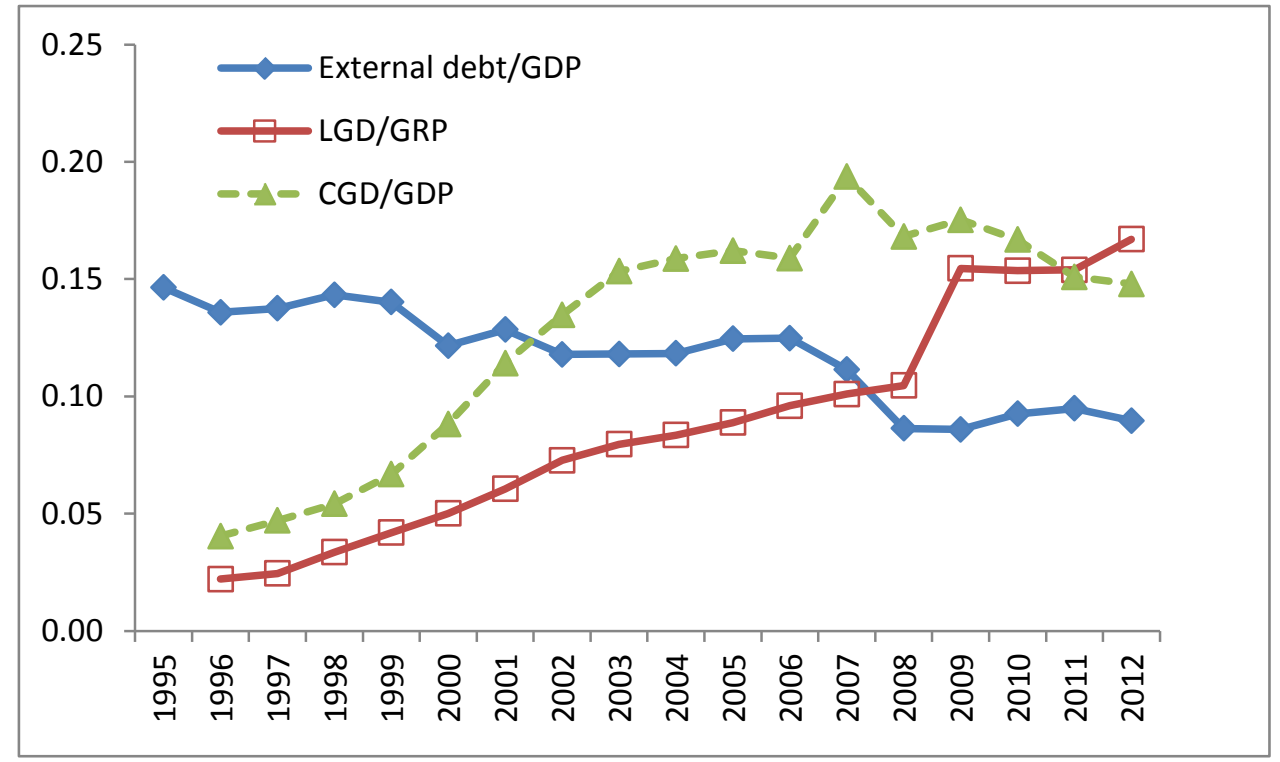

Notes: LGD and CGD are short for the local government debt and central government debt. Source: author's own work using data from NBS (various years).

Figure 1 Government debt ratios, 1995-2012

Overall, China's government debt-GDP ratio was about 40 per cent in 2012, which is well below the OECD average of 107.1 per cent, not to mention 216.5 per cent for Japan in the same year (OECD 2014). However, any assessment of government debt is complicated due to 
its coverage. In the official audit reports in both 2011 and 2013, information on three types of government debt was collected. These include 1) public holdings of debt directly owed by governments, 2) debt guaranteed by governments and 3) governments' contingent liabilities. So far, the government debt mentioned in this study refers to the first category, which comprises the dominant share of the combined debt of the central and local governments (Figure 3). At the end of June 2013, the share of guaranteed debt and contingent liabilities in the total debt of local governments was much larger than that of the central government (Figure 3). It is also reported that in recent years governments actually repaid at most some 19.1 per cent of total guaranteed debt and about 14.6 per cent of contingent liabilities in a single year (NAO 2013). In the long run, there are certainly risks involved in the management of government guaranteed debt and contingent liabilities. 


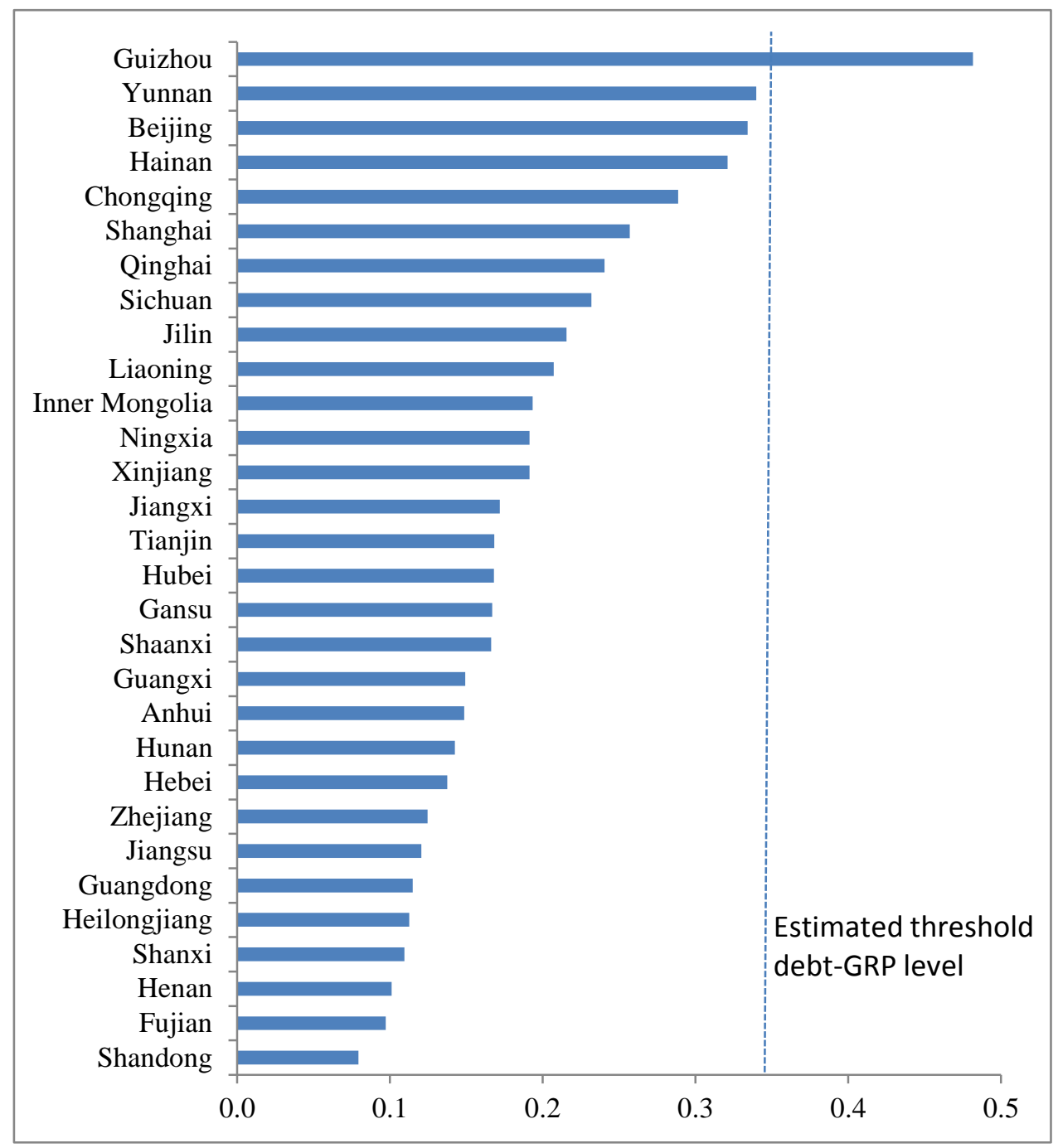

Sources: Author's own estimates.

Notes: Tibet is excluded due to missing data.

Figure 2 Debt-GRP Ratios by Region, 2012

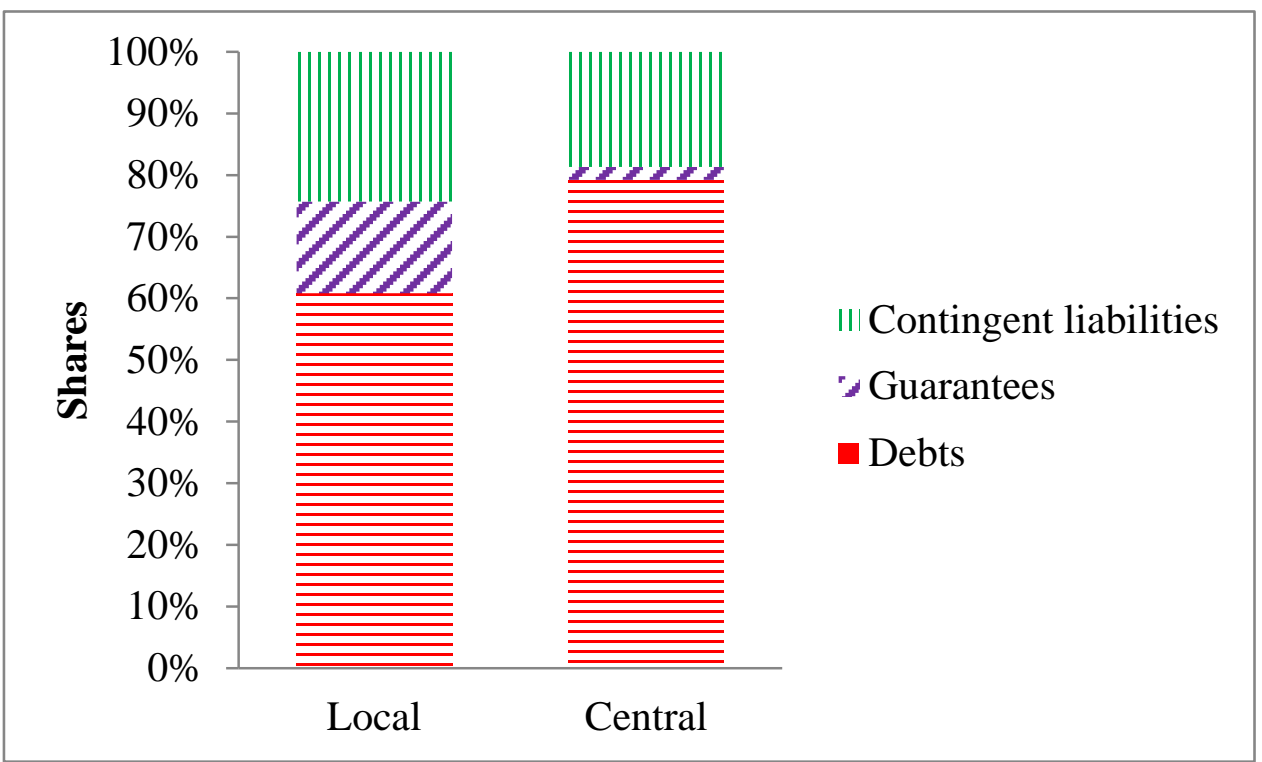

Sources: Author's own estimates.

Figure 3 Government Debt Composition (End of June 2013) 


\section{Modelling the Effects of Government Debt on Economic Growth}

To contribute to the understanding of LGD and its impacts, this section presents an empirical study of the effect of LGD on regional economic growth in China. The modelling and data issues are discussed first, followed by some preliminary analytical results.

\section{The Model}

The effect of government debt on regional economic growth can be examined using the conventional techniques of growth analysis, which are well developed in the literature (Barro 1991, Levine and Renelt 1992). These techniques have also been applied to the analysis of economic growth in China (Liu 2002, Chen and Wu 2012). This study will extend the existing literature by incorporating government debt related variables in the growth equation. ${ }^{4}$ Symbolically, a standard growth regression model can be expressed as

$$
y_{i t}=\alpha_{i}+\beta \ln \left(Y_{i, t-k}\right)+\gamma D_{i t}+\emptyset D_{i t}^{2}+\Sigma \delta_{j} X_{i j t}+\varepsilon_{i t}
$$

where $y, Y$ and $D$ respectively represent the growth rates, per capita income and debt level of the $i^{\text {th }}$ region in period $t$. The lagged $Y$ is used as a proxy for the initial income level. In the literature, researchers typically focused on five-year growth intervals (Barro 1991, Sala-i-Martin 1997). Therefore in this study a lag of five years is chosen for the initial income variable. A squared term is included to reflect a potential nonlinear relationship between growth and debt level. This non-linear relationship has recently been examined in a large pool

\footnotetext{
4 The existing literature considers the effect of external debt on economic growth in cross country analysis (Clements et al. 2003, Pattillo et al. 2002).
} 
of studies (Reinhart and Rogoff 2010, Pescatori et al. 2014).

$X$ is a set of region-specific control variables which may affect regional economic growth. The choice of these variables is widely discussed in the literature of cross-country studies. ${ }^{5}$ In the case of an individual country like China, the selection of these variables is also partly dictated by the availability of regional economic statistics. In addition, the empirical estimation of equation (1) will have to deal with the problem of endogeneity, as the relationship between economic growth and government debt could be bidirectional (Misztal 2010, Afonso and Hauptmeier 2009). Thus several optional estimation techniques are considered. These include the fixed and random effect models, the instrumental variable (IV) approach and GMM methods.

\section{Description of Variables}

The dependent variable is the real growth rate $(y)$ of GRP. The initial income variable $(Y)$ is the real GRP per capita lagged five years, expressed in constant (2005) prices. The precise measure of LGD level $(D)$ is controversial. In the literature, both gross and net debt values have been considered. The most popular indictor of the level of government debt is the debt-GDP ratio in a country or the debt-GRP ratio in a region. The empirical analysis in this study begins with the adoption of this definition, which defines $D$ as the ratio of LGD to GRP. The corresponding models are our baseline models. These will be extended by adopting an alternative measure of debt level, namely the ratio of LGD to government revenue. The corresponding models are the alternative models.

Five control variables $(X)$ are considered in this study. The first is a variable capturing

\footnotetext{
${ }^{5}$ More than 60 country-specific variables were considered by Sala-i-Martin (1997). For a regional study, the number of variables would be much smaller.
} 
population growth in the regions (pop), which may have a positive coefficient. Population growth could reflect aggregate demand and hence may be positively correlated with economic growth. The second control variable represents infrastructure development (inf), measured as the geometric mean of the density of railway lines and highways. Density here refers to both length per capita and length per square kilometer of land. The third variable captures the ratio of regional export values to GRP (ex). The fourth variable is the ratio of senior high school enrolment, which is used as a proxy for regional human capital $(h k) .{ }^{6}$ Finally the fifth control variable is the ratio of capital formation to GRP (cap). The last four variables are also expected to have positive coefficients. Summary information about the chosen variables is presented in Table 1.

Table 1 Summary Statistics of the Variables

\begin{tabular}{lcccr}
\hline Variables & Mean & Standard deviation & Min & Max \\
& & & & \\
Growth & 0.1235 & 0.0213 & 0.0746 & 0.1740 \\
Debt/GRP & 0.1879 & 0.0948 & 0.0661 & 0.5642 \\
Debt/revenue & 1.8000 & 0.6932 & 0.8754 & 4.8142 \\
log(GRP pc) & 9.6642 & 0.5466 & 8.5275 & 11.0631 \\
Infrastructure & 0.2292 & 0.0469 & 0.1325 & 0.3188 \\
Population growth & 0.0081 & 0.0147 & -0.0520 & 0.0563 \\
Capital/GRP & 0.6169 & 0.1373 & 0.3803 & 0.9252 \\
Human capital & 0.9060 & 0.1314 & 0.6224 & 1.3307 \\
Export/GRP & 0.1476 & 0.1808 & 0.0132 & 0.7037 \\
& & & & \\
\hline
\end{tabular}

Source: Author's own estimates.

As shown in the table, China's regions on average achieved an annual growth rate of 12.35 per cent during 2010-2012. ${ }^{7}$ Table 1 also shows that the average LGD-GRP ratio is 18.79 per cent while the mean ratio of LGD to government revenue is 180 per cent. There are

\footnotetext{
${ }^{6}$ Note that some authors have attempted to measure China’s human capital in alternative ways (Wang and Yao 2003, Li et al. 2014).

${ }^{7}$ It should be pointed out that there is an inconsistency between China's national and regional growth rates.
} 
also considerable regional variations, which are reflected in the large difference between the minimum and maximum values and by the magnitude of standard deviation in Table 1.

\section{Preliminary Estimation Results}

Empirical estimation of equation (1) starts with the simple version without control variables $(X)$. The sample covers the period 2010-2012 for 30 Chinese regions (Tibet is excluded due to missing data). The initial estimation involves three methods: the pooled regression (PR), fixed effect (FE) and random effect (RE) models. The results are presented in Table 2. The Hausman statistic tests RE against FE, and the Baltagi-Li value can be used to verify the FE model against the PR specification. For interpretation, linear models (1) and (4) are examined first. The large p-value obtained in the Baltagi-Li test implies that the PR model (1) is preferred to the FE model (4) while the RE model is rejected by Hausman test (RE model results are thus not reported in the table). In models (1) and (4), the estimated coefficient of the debt variable is statistically insignificant, implying that the relationship between government debt and economic growth may not be linear.

For the simple version of the nonlinear models (2) and (5), the FE model is the preferred one according to both the Baltagi-Li and Hausman tests. The estimated coefficients of the debt and debt-squared variables are statistically significant at the level of 5 per cent. The results thus support a nonlinear relationship between government debt and regional economic growth. The derived turning point or threshold level is a debt-GRP ratio of about 35 per cent. In addition, the estimation results for the FE model (5) show a negative and significant coefficient of the initial income variable, which implies growth convergence in Chinese regions during the decade considered. 
Table 2 Estimation Results for Baseline Models

\begin{tabular}{|c|c|c|c|c|c|c|}
\hline & & Pooled regression & & $\underline{\text { Fixed effe }}$ & ct models & \\
\hline & (1) & (2) & (3) & (4) & (5) & (6) \\
\hline Debt/GRP & $0.0134(0.5352)$ & $0.1288(0.0817)^{*}$ & $0.0761(0.3367)$ & $0.0407(0.5375)$ & $0.3716(0.0389)^{* *}$ & $0.4348(0.0287)^{* *}$ \\
\hline Debt/GRP ${ }^{2}$ & & $-0.2144(0.1026)$ & $-0.1300(0.3576)$ & & $-0.5351(0.0483)^{* *}$ & $-0.6042(0.0393)^{* *}$ \\
\hline $\log ($ initial income) & $-0.0195(0.0000)^{* * *}$ & $-0.0207(0.0000)^{* * *}$ & $-0.0338(0.0000)^{* * *}$ & $-0.1126(0.0000)^{* * *}$ & $-0.1200(0.0000)^{* * *}$ & $-0.1161(0.0000)^{* * *}$ \\
\hline Infrastructure & & & $0.0678(0.1660)$ & & & $-0.0415(0.8787)$ \\
\hline Population & & & $0.3674(0.0218)^{* *}$ & & & $0.2180(0.0681)^{*}$ \\
\hline Investment & & & $0.0207(0.2181)$ & & & $-0.0314(0.4759)$ \\
\hline Human capital & & & $0.0247(0.2000)$ & & & $-0.0344(0.2023)$ \\
\hline Trade & & & $0.0237(0.2263)$ & & & $-0.0524(0.4916)$ \\
\hline Constant & $0.3089(0.000)^{* * *}$ & $0.3091(0.0000)^{* * *}$ & $0.3843(0.0000)^{* * *}$ & & & \\
\hline Adjusted $\mathrm{R}^{2}$ & 0.2532 & 0.2676 & 0.3386 & 0.8141 & 0.8233 & 0.8229 \\
\hline Log likelihood & 233.28 & 234.68 & 241.96 & 314.11 & 317.17 & 321.21 \\
\hline Baltagi-Li test & $1.6829(0.1945)$ & $3.6008(0.0578) *$ & $4.4092(0.0357)^{* *}$ & & & \\
\hline Hausman test & & & & $66.63(0.000)^{* * *}$ & $73.31(0.0000)^{* * *}$ & $59.37(0.0000)^{* * *}$ \\
\hline Threshold level & & 0.3004 & 0.2928 & & 0.3472 & 0.3631 \\
\hline
\end{tabular}

Source: Author's own estimates.

Note: p-values in parentheses. 
The second set of the estimated models extends the simple version of equation (1) by incorporating region-specific control variables, so that these can be called the augmented models. The Hausman test shows that the FE model (6) is the preferred model (Table 2). The estimation results confirm the non-linear relationship between government debt and economic growth, which implies a threshold debt-GRP ratio of about 36 per cent. The estimated threshold debt-GRP level in both the simple and augmented models is much lower than the controversial 90 per cent level reported by Reinhart and Rogoff (2010). However, in the empirical literature, the estimated threshold level for developing economies is generally lower than that for the developed economies. For example, Pattillo et al. (2002) obtained a figure of 35-40 per cent for the period of 1969-98, and Clements et al. (2003) reported 20-25 per cent for developing economies. Furthermore the estimated coefficient of the initial income variable is statistically significant with the right sign. It thus again implies growth convergence among the Chinese regions in recent years. In addition, note that the coefficients of the control variables are either insignificant or significant with the wrong sign. This calls for further investigation of the modelling exercises. For example, one potential problem is the existence of multicollinearity among the regressors (Table 3). This problem is to be dealt with later via an extension of the sample and use of the GMM estimation technique. 
Table 3 Correlation coefficient matrix for regressors

\begin{tabular}{lllllllllll}
\hline Debt/GRP & 1 & & & & & & & \\
Debt/GRP squared & 0.9598 & 1 & & & & & & \\
log(GRP pc) & -0.2986 & -0.3414 & 1 & & & & & & & \\
Infrastructure & -0.0297 & -0.0198 & 0.1322 & 1 & & & & & \\
Population growth & -0.0231 & -0.0882 & 0.5482 & 0.2110 & 1 & & & & \\
Capital/GRP & 0.1071 & 0.0398 & -0.3801 & 0.1354 & -0.1054 & 1 & & & \\
Human capital & -0.1979 & -0.2855 & 0.5778 & 0.2487 & 0.4104 & -0.0055 & 1 & & \\
Export/GRP & -0.2262 & -0.2012 & 0.7081 & -0.2675 & 0.3308 & -0.5540 & 0.1911 & 1
\end{tabular}

Source: Author's own estimates.

The above-derived threshold debt-GRP level is well above the current mean (16.7 per cent) for the Chinese regions for the recent decade (see Figure 1). At the provincial level, only Guizhou's debt-GRP ratio (48.2 per cent) exceeded the estimated threshold level in 2012 (Figure 2). Several regions' debt-GRP ratios were also close to the threshold level. These include Yunnan (34.0 Per cent), Beijing (33.4 per cent) and Hainan (32.1 per cent). Therefore the optimistic view of China's regional debt conditions expressed by scholars such as Fan and Lv (2012) is supported here. It seems that most Chinese regional economies are yet to reach the turning point for the debt-GRP ratio. This is of course based on the narrow definition of government debt, which excludes debt guaranteed by governments and contingent liabilities.

\section{Further Analyses}

Empirical exercises in the preceding section may suffer from several shortcomings due to possible bias in the definition of government debt, the limitation of a small sample 
and the problem of endogeneity. These issues are addressed one by one in this section.

\subsection{Alternative Measure of Government debt}

The measurement of government debt is controversial. In the preceding section, the conventional debt-GRP ratio was used. An alternative measure is the ratio of government debt to government revenue, the $D-R$ ratio. The exercises reported in Section 3 are repeated, using D-R, and the results are given in Table 4. Clearly the new results are consistent with the findings in Section 3. A non-linear relationship is again confirmed. The implied threshold D-R ratio is around 266-270 per cent. Guizhou is the only region which exceeded the estimated threshold D-R ratio in 2012 (with an actual ratio of 325 per cent). This is similar to the case with the debt-GRP ratio, Other regions with a D-R ratio close to the threshold level include Yunnan (262 per cent), Jilin (247 per cent) and Qinghai (244 per cent). It should be pointed out that Guizhou, Yunnan and Qinghai are all less developed western regions. Furthermore the estimated coefficients of the control variables are hardly significant statistically. This will be explored further. Overall, it can be concluded that the two measures of LGD lead to consistent estimates and hence to consistent findings. 
Table 4 Results for Alternative Measures of Government debt

\begin{tabular}{|c|c|c|c|c|c|c|}
\hline Variables & (7) & (8) & (9) & $(10)$ & (11) & $(12)$ \\
\hline Debt/Revenue & $0.0050(0.1456)$ & $0.0214(0.0604)^{*}$ & $0.0170(0.1665)$ & $-0.0038(0.4954)$ & $0.0399(0.0101)^{* *}$ & $0.0439(0.1115)$ \\
\hline Debt/Revenue ${ }^{2}$ & & $-0.0034(0.1300)$ & $-0.0027(0.2688)$ & & $-0.0075(0.0029) * * *$ & $-0.0081(0.0037)^{* * *}$ \\
\hline $\log$ (initial income) & $-0.0165(0.0003) * * *$ & $-0.0158(0.0004)^{* * *}$ & $-0.0307(0.0001)^{* * *}$ & $-0.1154(0.000) * * *$ & $-0.1108(0.0000)^{* * *}$ & $-0.1071(0.0000) * * *$ \\
\hline Infrastructure & & & $0.0742(0.1272)$ & & & $-0.0239(0.9272)$ \\
\hline Population & & & $0.3589(0.0214)^{* *}$ & & & 0.1582 (0.1723) \\
\hline Investment & & & $0.0197(0.2326)$ & & & $-0.0214(0.6071)$ \\
\hline Human capital & & & $0.0251(0.1862)$ & & & $-0.0400(0.1268)$ \\
\hline Trade & & & $0.0274(0.1663)$ & & & $-0.0572(0.4322)$ \\
\hline Constant & $0.2738(0.000)^{* * *}$ & $0.2505(0.0000)^{* * *}$ & $0.3409(0.0000) * * *$ & & & \\
\hline Adjusted $\mathrm{R}^{2}$ & 0.2680 & 0.2791 & 0.3526 & 0.8144 & 0.8379 & 0.8361 \\
\hline Log likelihood & 234.18 & 235.39 & 242.92 & 314.18 & 321.05 & 324.68 \\
\hline Baltagi-Li test & $1.3974(0.2374)$ & $2.7441(0.0976)^{*}$ & $3.7415(0.0531)^{*}$ & & & \\
\hline Hausman test & & & & $67.61(0.0000)^{* * *}$ & $78.56(0.0000) * * *$ & $62.04(0.0000)^{* * *}$ \\
\hline Threshold level & & 3.1105 & 3.1716 & & 2.6600 & 2.7099 \\
\hline
\end{tabular}

Source: Author's own estimates.

Note: p-values in parentheses. 


\subsection{An Extended Database}

An important weakness in the above-mentioned exercises is the short (three-year) period of the sample. To extend the database, the mean growth rates of LGD for 2010-2012 and the growth rate of total government debt for 2003-2012 are combined to generate a dataset covering 10 years (2003-2012) for all 30 regions. The exercises conducted in Section 3 are repeated using the extended database for both measures of government debt. The results are presented in Table 5. To save space, only the results for the augmented FE model are reported, as the PR and RE models are always rejected by the Baltagi-Li and Hausman tests. It is shown that none of the estimated coefficients of the debt-GRP ratio variables is statistically significant (Table 5). However, the model involving the D-R ratio variables is acceptable and the findings are consistent with those from the baseline models. Furthermore, all control variables in model (14) are statistically significant.

\subsection{Endogeneity}

Within the group of studies of government debt, a major stream of the literature has focused on the causality between government debt and economic growth. Thus the exercises conducted so far in this study may suffer from the problem of endogeneity. To deal with this concern, several options exist as regards estimation methods. These include the use of lags and instrumental variables (IVs) and the associated estimation techniques. The extended database makes it possible to introduce lags into the model. 
Table 5 Estimates for the Extended Database

\begin{tabular}{lcc}
\hline & $(13)$ & $(14)$ \\
Debt/GRP & $0.0864(0.1082)$ & \\
Debt/GRP & & \\
Debt/Revenue & $-0.0278(0.7692)$ & $0.0208(0.0005)^{* * *}$ \\
Debt/Revenue & & $-0.0036(0.0010)^{* * *}$ \\
log(initial income) & $-0.0652(0.0000)^{* * *}$ & $-0.0611(0.0000)^{* * *}$ \\
Infrastructure & $0.2136(0.0000)^{* * *}$ & $0.1860(0.0003)^{* * *}$ \\
Population & $0.3265(0.0072)^{* * *}$ & $0.2450(0.0437)^{* *}$ \\
Investment & $0.0750(0.0000)^{* * *}$ & $0.0829(0.0000)^{* * *}$ \\
Human capital & $0.0320(0.0394)^{* *}$ & $0.0262(0.0912)^{*}$ \\
Trade & $0.0620(0.0065)^{* * *}$ & $0.0591(0.0092)^{* * *}$ \\
Adjusted $\mathrm{R}^{2}$ & 0.4750 & 0.4810 \\
Log likelihood & 833.9700 & 835.6900 \\
Hausman test & $29.0300(0.0003)^{* * *}$ & $29.6300(0.0002)^{* * *}$ \\
Baltagi-Li test & $65.6883(0.0000)^{* * *}$ & $72.8379(0.0000)^{* * *}$ \\
Threshold level & & 2.8889 \\
& & \\
\hline
\end{tabular}

Source: Author's own estimates.

Note: p-values in parentheses.

First, an IV measuring the mean debt-GRP ratio of neighbouring regions of each province is introduced to replace the debt variable in the models. The estimation results are reported in Table 6, which only reports regressions using the extended sample and augmented model. The debt variables have the expected signs and nonlinearity is also confirmed. For the first measure of debt, none of the estimated coefficients is statistically significant (model 15, Table 6). Thus the model is poorly fitted. For the second measure of debt, the estimated model is much better. The estimated coefficients have the expected sign and a nonlinear relationship between government debt and economic growth is also observed (model 18, Table 6). To improve the estimation, the lagged debt variable is also added as an IV. The regressions are repeated using three IVs: the mean debt-GRP ratio of neighbouring regions, the $1^{\text {st }}$ order lagged debt variable, 
and the $2^{\text {nd }}$ order lagged debt variable (Models 16 and 19, Table 6). For both debt measures, the estimation results are improved in terms of the expected sign and level of significance and are generally consistent with those of the baseline models. A further option in this category is the use of a two stage least squares (2SLS) method (Models 17 and 20, Table 6). The mean debt-GRP ratio of neighbouring regions and all exogenous variables are used as IVs. Once again the results are in general consistent with those of the baseline models. For the first measure of government debt, the estimated threshold debt level ranges from 26.14 per cent to 38.04 per cent. For the second measure of government debt, the estimated threshold value ranges from 259 to 288 per cent. In addition, there is some improvement in the estimated coefficients of the control variables in terms of the sign and level of significance.

The second attempt involves the application of the popular GMM method, which may be appropriate for panel data models suffering from endogeneity and multi-collinearity. Two models are considered. One is the augmented model discussed in Section 3, which is estimated using the GMM technique (models 21 and 22, Table 7). The other is a dynamic panel data model (DPDM), which includes the lagged dependent variable (growth rate) as an explanatory variable (models 23 and 24, Table 7). The advantage of adopting a DPDM framework is its ability to capture persistence in the pattern of economic growth. GMM involves the use of a large number of IVs generated internally. Thus it is important to test the validity of instruments or the problem of over-identification. The J-statistic or Sargan value can be used for this purpose. In general the J-statistics in Table 7 have large p-values and so cannot reject 
the null hypothesis that the over-identifying restrictions are valid. In general the GMM estimation results are much better in terms of the level of significance and signs of the estimated coefficients. The results also confirm nonlinearity, which implies a slightly higher threshold level of debt than in the other models. This level (52-58 per cent in models 21 and 22) is nevertheless well beyond the current debt level in Chinese regional economies. Thus the message is still that China's regional debt is in the safe zone.

Table 6 Results for Models with IVs, Lagged Variables and 2SLS

\begin{tabular}{lccc}
\hline Variables & IV only & IV and lags & 2SLS \\
& $(15)$ & $(16)$ & $(17)$ \\
Debt/GRP & $4.2102(0.2328)$ & $0.4093(0.0796)^{*}$ & $0.1799(0.0598)^{*}$ \\
Debt/GRP & $-6.5445(0.2409)$ & $-0.5380(0.1474)$ & $-0.3441(0.1041)$ \\
log(initial income) & $-0.3193(0.1480)$ & $-0.0851(0.0000)^{* * *}$ & $-0.0147(0.0001)^{* * *}$ \\
Infrastructure & $0.6706(0.1464)$ & $0.2494(0.0000)^{* * *}$ & $0.0215(0.3980)$ \\
Population & $1.3157(0.2008)$ & $0.4040(0.0041)^{* * *}$ & $-0.0625(0.5345)$ \\
Investment & $0.1969(0.1384)$ & $0.0846(0.0000)^{* * *}$ & $0.0487(0.0001)^{* * *}$ \\
Human capital & $-0.0941(0.4732)$ & $0.0221(0.2170)$ & $0.0361(0.0004)^{* * *}$ \\
Trade & $-0.1888(0.4324)$ & $0.0424(0.1281)$ & $0.0245(0.0070)^{* * *}$ \\
Threshold level & 0.3217 & 0.3804 & 0.2614 \\
& & & \\
& $(18)$ & $(19)$ & $(20)$ \\
Debt/Revenue & $0.1070(0.0002)^{* * *}$ & $0.0985(0.0002)^{* * * *}$ & $0.0374(0.0071)^{* * *}$ \\
Debt/Revenue & $-0.0186(0.0002)^{* * *}$ & $-0.0171(0.0002)^{* * *}$ & $-0.0072(0.0117)^{* *}$ \\
log(initial income) & $-0.0826(0.0000)^{* * *}$ & $-0.0804(0.0000)^{* * *}$ & $-0.0138(0.0003)^{* * *}$ \\
Infrastructure & $0.1471(0.0347)^{* *}$ & $0.1509(0.0236)^{* *}$ & $-0.0016(0.9560)$ \\
Population & $0.2671(0.1024)$ & $0.2649(0.0906)^{* *}$ & $0.0083(0.9338)$ \\
Investment & $0.1213(0.0000)^{* * *}$ & $0.1176(0.0000)^{* * * *}$ & $0.0379(0.0054)^{* * *}$ \\
Human capital & $-0.0095(0.6884)$ & $-0.0060(0.7904)$ & $0.0428(0.0000)^{* * *}$ \\
Trade & $0.0109(0.7483)$ & $0.0156(0.6285)$ & $0.0217(0.0186)^{* *}$ \\
Threshold level & 2.8794 & 2.8796 & 2.5929 \\
& & & \\
\hline & & &
\end{tabular}

Source: Author's own estimates.

Note: p-values in parentheses. 
Table 7 GMM estimation results

\begin{tabular}{lcccc}
\hline Variables & $(21)$ & $(22)$ & $(23)$ & $(24)$ \\
Growth(-1) & & & $-0.2055(0.0000)^{* * *}$ & $-0.2003(0.0000)^{* * *}$ \\
Debt/GRP & $0.1918(0.0004)^{* * *}$ & & $0.1993(0.0000)^{* * *}$ & \\
Debt/GRP & $-0.1840(0.0244)^{* *}$ & & $-0.1718(0.0127)^{* *}$ & \\
Debt/Revenue & & $0.0563(0.0000)^{* * *}$ & & $0.0330(0.0000)^{* * *}$ \\
Debt/Revenue & & $-0.0102(0.0000)^{* * *}$ & & $-0.0050(0.0000)^{* * *}$ \\
log(initial income) & $-0.0527(0.0000)^{* * *}$ & $-0.0540(0.0000)^{* * *}$ & $-0.0628(0.0000)^{* * *}$ & $-0.0557(0.0000)^{* * *}$ \\
Infrastructure & $0.1514(0.0000)^{* * *}$ & $0.1418(0.0007)^{* * *}$ & $0.1734(0.0000)^{* * *}$ & $0.1669(0.0000)^{* * *}$ \\
Population & $0.2787(0.0003)^{* * *}$ & $0.1613(0.0459)^{* *}$ & $0.1688(0.0146)^{* *}$ & $0.1391(0.0274)^{* *}$ \\
Investment & $0.0310(0.0197)^{* *}$ & $0.0322(0.0187)^{* *}$ & $-0.0126(0.2777)$ & $-0.0088(0.4425)$ \\
Human capital & $0.0005(0.0000)^{* * *}$ & $0.0003(0.0062)^{* * *}$ & $0.0005(0.0000)^{* * *}$ & $0.0004(0.0000)^{* * *}$ \\
Trade & $0.0858(0.0000)^{* * *}$ & $0.0949(0.0000)^{* * *}$ & $0.0773(0.0001)^{* * *}$ & $0.0770(0.0000)^{* * *}$ \\
J-statistic & $26.0258(0.0537)^{*}$ & $24.3103(0.0829)^{*}$ & $28.3128(0.1315)$ & $28.5982(0.1240)$ \\
Threshold level & 0.5214 & 2.7669 & 0.5800 & 3.3164
\end{tabular}

Source: Author's own estimates.

Note: p-values in parentheses. 


\section{Conclusion}

This paper adopts traditional growth regression analysis techniques to examine the impact of government debt on economic performance in China's regional economies. The empirical findings confirm the existence of a non-linear relationship between economic growth and local government debt (LGD). The threshold level of government debt in China is found to be much lower than that observed in most studies of OECD economies. It is also shown that almost all Chinese regions are still below the threshold debt level. This may help reduce the anxiety about China's LGD for the time being.

Our findings do reveal significant regional differences. Some regions’ debt-GRP ratios are close to the threshold debt level. Thus region-specific approaches should be adopted in order to deal with regional debt problems. This is particularly the case for China's less developed regions, which are financially less flexible in terms of debt repayment. The debt ratio in some western regions, for example, is rising fast and leading the rest of the country to approach the estimated threshold level. If the trend is maintained, those regions may to pay a price for being heavily indebted in the long run. Furthermore, to deal with LGD issues effectively, more information is needed about debt at the county and township level. These lower levels of government and their debt situations are not covered by this study. 


\section{References}

Afonso, António and João Tovar Jalles (2013), “Growth and Productivity: The Role of Government Debt”, International Review of Economics and Finance 25(C), $384-407$.

Afonso, António and Sebastian Hauptmeier (2009), "Public Debt and Economic Growth: a Granger Causality Panel Data Approach”, Working Papers No 2009/24, School of Economics and Management, University of Lisbon.

Azzimonti, M., E.D. Francisco and V. Quadrini (2014), “Financial Globalisation, Inequality and the Rising Public Debt”, American Economic Review 104(8), 2267-2302.

Barro, Robert Joseph (1991), "Economic Growth in a Cross Section of Countries,” Quarterly Journal of Economics 106 (2), 407-43.

Baum, Cristina Anja, Checherita-Westphal and Philipp Rother (2013), "Debt and Growth: New Evidence for the Euro Area”, Journal of International Money and Finance 32(C), 809-821.

Chen, Yu and Yanrui Wu (2012), "Regional Economic Growth and Spillover Effects: An Analysis of China’s Pan Pearl River Delta Area”, China \& World Economy 20(2), 80-97.

Clements, Benedict J., Rina Bhattacharya and Toan Quoc Nguyen (2003), “External Debt, Public Investment, and Growth in Low-Income Countries”, IMF Working Paper 03/249, Washington DC. 
Corsetti, Giancarlo, Keith Kuester, André Meier and Gernot J. Müller (2010), “Debt Consolidation and Fiscal Stabilization of Deep Recessions”, American Economic Review 100(2), 41-45.

ECB, 2014, “Convergence Criteria”, online document, the European Central Bank (http://www.ecb.europa.eu/ecb/orga/escb/html/convergence-criteria.en.html).

Editorial Board (2013), Finance Yearbook of China 2012, Beijing: China Finance Magazine Press.

Egert, Balazs (2013), "Public Debt, Economic Growth and Nonlinear Effects: Myth or Reality”, CESifo Working Paper Series No 4157, Munich.

Fan, Gang and Yan Lv (2012), "Fiscal Prudence and Growth Sustainability: An Analysis of China's Public Debts”, Asian Economic Policy Review 7(2), 202-220.

Herndon, Thomas, Michael Ash and Robert Pollin (2014), “Does High Public Debt Consistently Stifle Economic Growth? A Critique of Reinhart and Rogoff”, Cambridge Journal of Economics (in press).

Krueger, A.O. (1987), “Debt, Capital Flows, and LDC Growth”, American Economic Review 77(2), 159-64.

Krugman, Paul (1988), “Financing versus Forgiving a Debt Overhang”, Journal of Development Economics 29, 253-268.

Levine, Ross and David Renelt (1992), “A Sensitivity Analysis of Cross-country Growth Regressions”, American Economic Review 82(4), 942-63.

Li, Haizheng, Qinyi Liu, Bo Li, Barbara Fraumeni and Xiaobei Zhang (2014), “Human Capital Estimates in China: New Panel Data 1985-2010”, China Economic Review 
30, 397-418.

Liu, Z. (2002), “Foreign Direct Investment and Technology Spillover: Evidence from China”, Journal of Comparative Economics 30 (3), 579-602.

Misztal, Piotr (2010), “Public Debt and Economic Growth in the European Union”, Journal of Applied Economic Sciences 5(3), 292-302.

Modigliani, F. (1961), “Long-Run Implications of Alternative Fiscal Policies and the Burden of the National Debt”, Economic Journal 71 (284), 730-755.

NAO (2011), Auditing Report of Local Government Debts, document no.35, the National Audit Office (NAO), Beijing.

NAO (2013), Auditing Report of Local Government Debts, document no.35, the National Audit Office (NAO), Beijing.

OECD (2014), Key Tables from OECD, www.OECD-ilibrary.org.

Panizza, Ugo and Andrea F. Presbitero (2013), “Public Debt and Economic Growth in Advanced Economies: A Survey”, Swiss Journal of Economics and Statistics (SJES) 149(II), 175-204.

Pattillo, Catherine A., Hélène Poirson and Luca A. Ricci (2002), “External Debt and Growth”, IMF Working Paper 02/69, Washington DC.

Pei, Yu (2009), “Local governmental pre-alarm system of debt risk: a frame design”, Journal of Information and Optimization Sciences, 30(3), 601-618.

Pescatori, Andrea, Damiano Sandri and John Simon (2014), “Debt and Growth: Is There a Magic Threshold?”, IMF Working Paper No. 14/34, Washington DC. Rajan, Raghuram G. (2012), “The True Lessons of the Recession: The West Can’t 
Borrow and Spend Its Way to Recovery”, Foreign Affairs, May/June.

Reinhart, Carmen M, Vincent R Reinhart, and Kenneth S Rogoff (2012), Public Debt Overhangs: Advanced-Economy Episodes since 1800”, Journal of Economic Perspectives 26(3), 69-86.

Reinhart, Carmen M. and Kenneth S. Rogoff (2010), “Growth in a Time of Debt”, American Economic Review 110(2), 573-78.

Saint-Paul, Gilles (1992), "Fiscal Policy in an Endogenous Growth Model”, Quarterly Journal of Economics 107(4), 1243-59.

Sala-i-Martin, X (1997), “I Just Ran Two Million Regressions”, American Economic Review 87(2), 178-83.

Smyth, D. J. and Y. Hsing (1995), “In Search of An Optimal Debt Ratio for Economic Growth”, Contemporary Economic Policy 13, 51-59.

The Economist (2009), “Government debt: The big sweat”, June 11.

Tsui, Kai Yuen (2011), “China's infrastructure investment boom and local debt crisis”, Eurasian Geography and Economics 52(5), 686-711.

Wang, Yan and Yudong Yao (2003), “Sources of China's Economic Growth 1952-1999: Incorporating Human Capital Accumulation”, China Economic Review 14 (1), $32-52$.

Wu, Yanrui (2004), China’s Economic Growth: A Miracle with Chinese Characteristics, Routledge, London and New York.

Wu, Yanrui (2008), Productivity, Efficiency and Economic Growth in China, Palgrave, London. 
Editor, UWA Economics Discussion Papers:

Sam Hak Kan Tang

University of Western Australia

35 Sterling Hwy

Crawley WA 6009

Australia

Email: ecoadmin@biz.uwa.edu.au

The Economics Discussion Papers are available at:

1980 - 2002: $\quad$ http://ecompapers.biz.uwa.edu.au/paper/PDF\%20of\%20Discussion\%20Papers/

Since 2001: http://ideas.repec.org/s/uwa/wpaper1.html

Since 2004: http://www.business.uwa.edu.au/school/disciplines/economics

\begin{tabular}{|c|c|c|}
\hline \multicolumn{3}{|c|}{$\begin{array}{l}\text { ECONOMICS DISCUSSION PAPERS } \\
2013\end{array}$} \\
\hline $\begin{array}{l}\text { DP } \\
\text { NUMBER }\end{array}$ & AUTHORS & TITLE \\
\hline 13.01 & $\begin{array}{l}\text { Chen, M., Clements, K.W. and } \\
\text { Gao, G. }\end{array}$ & THREE FACTS ABOUT WORLD METAL PRICES \\
\hline 13.02 & Collins, J. and Richards, O. & $\begin{array}{l}\text { EVOLUTION, FERTILITY AND THE AGEING } \\
\text { POPULATION }\end{array}$ \\
\hline 13.03 & $\begin{array}{l}\text { Clements, K., Genberg, H., Harberger, } \\
\text { A., Lothian, J., } \\
\text { Mundell, R., Sonnenschein, H. and } \\
\text { Tolley, G. }\end{array}$ & LARRY SJAASTAD, 1934-2012 \\
\hline 13.04 & Robitaille, M.C. and Chatterjee, I. & MOTHERS-IN-LAW AND SON PREFERENCE IN INDIA \\
\hline 13.05 & Clements, K.W. and Izan, I.H.Y. & $\begin{array}{l}\text { REPORT ON THE } 25^{\mathrm{TH}} \text { PHD CONFERENCE IN } \\
\text { ECONOMICS AND BUSINESS }\end{array}$ \\
\hline 13.06 & Walker, A. and Tyers, R. & QUANTIFYING AUSTRALIA’S “THREE SPEED” BOOM \\
\hline 13.07 & $\mathrm{Yu}, \mathrm{F}$. and $\mathrm{Wu}, \mathrm{Y}$. & PATENT EXAMINATION AND DISGUISED PROTECTION \\
\hline 13.08 & Yu, F. and Wu, Y. & $\begin{array}{l}\text { PATENT CITATIONS AND KNOWLEDGE SPILLOVERS: } \\
\text { AN ANALYSIS OF CHINESE PATENTS REGISTER IN THE } \\
\text { US }\end{array}$ \\
\hline 13.09 & Chatterjee, I. and Saha, B. & BARGAINING DELEGATION IN MONOPOLY \\
\hline 13.10 & Cheong, T.S. and Wu, Y. & $\begin{array}{l}\text { GLOBALIZATION AND REGIONAL INEQUALITY IN } \\
\text { CHINA }\end{array}$ \\
\hline 13.11 & Cheong, T.S. and Wu, Y. & INEQUALITY AND CRIME RATES IN CHINA \\
\hline 13.12 & Robertson, P.E. and Ye, L. & ON THE EXISTENCE OF A MIDDLE INCOME TRAP \\
\hline 13.13 & Robertson, P.E. & THE GLOBAL IMPACT OF CHINA'S GROWTH \\
\hline 13.14 & $\begin{array}{l}\text { Hanaki, N., Jacquemet, N., } \\
\text { Luchini, S., and Zylbersztejn, A. }\end{array}$ & $\begin{array}{l}\text { BOUNDED RATIONALITY AND STRATEGIC } \\
\text { UNCERTAINTY IN A SIMPLE DOMINANCE SOLVABLE } \\
\text { GAME }\end{array}$ \\
\hline 13.15 & $\begin{array}{l}\text { Okatch, Z., Siddique, A. and } \\
\text { Rammohan, A. }\end{array}$ & $\begin{array}{l}\text { DETERMINANTS OF INCOME INEQUALITY IN } \\
\text { BOTSWANA }\end{array}$ \\
\hline 13.16 & Clements, K.W. and Gao, G. & $\begin{array}{l}\text { A MULTI-MARKET APPROACH TO MEASURING THE } \\
\text { CYCLE }\end{array}$ \\
\hline
\end{tabular}




\begin{tabular}{|c|c|c|}
\hline 13.17 & Chatterjee, I. and Ray, R. & $\begin{array}{l}\text { THE ROLE OF INSTITUTIONS IN THE INCIDENCE OF } \\
\text { CRIME AND CORRUPTION }\end{array}$ \\
\hline 13.18 & Fu, D. and Wu, Y. & $\begin{array}{l}\text { EXPORT SURVIVAL PATTERN AND DETERMINANTS } \\
\text { OF CHINESE MANUFACTURING FIRMS }\end{array}$ \\
\hline 13.19 & Shi, X., Wu, Y. and Zhao, D. & $\begin{array}{l}\text { KNOWLEDGE INTENSIVE BUSINESS SERVICES AND } \\
\text { THEIR IMPACT ON INNOVATION IN CHINA }\end{array}$ \\
\hline 13.20 & $\begin{array}{l}\text { Tyers, R., Zhang, Y. and } \\
\text { Cheong, T.S. }\end{array}$ & $\begin{array}{l}\text { CHINA'S SAVING AND GLOBAL ECONOMIC } \\
\text { PERFORMANCE }\end{array}$ \\
\hline 13.21 & Collins, J., Baer, B. and Weber, E.J. & $\begin{array}{l}\text { POPULATION, TECHNOLOGICAL PROGRESS AND THE } \\
\text { EVOLUTION OF INNOVATIVE POTENTIAL }\end{array}$ \\
\hline 13.22 & Hartley, P.R. & THE FUTURE OF LONG-TERM LNG CONTRACTS \\
\hline 13.23 & Tyers, R. & $\begin{array}{l}\text { A SIMPLE MODEL TO STUDY GLOBAL } \\
\text { MACROECONOMIC INTERDEPENDENCE }\end{array}$ \\
\hline 13.24 & McLure, M. & $\begin{array}{l}\text { REFLECTIONS ON THE QUANTITY THEORY: PIGOU IN } \\
1917 \text { AND PARETO IN 1920-21 }\end{array}$ \\
\hline 13.25 & Chen, A. and Groenewold, N. & $\begin{array}{l}\text { REGIONAL EFFECTS OF AN EMISSIONS-REDUCTION } \\
\text { POLICY IN CHINA: THE IMPORTANCE OF THE } \\
\text { GOVERNMENT FINANCING METHOD }\end{array}$ \\
\hline 13.26 & Siddique, M.A.B. & $\begin{array}{l}\text { TRADE RELATIONS BETWEEN AUSTRALIA AND } \\
\text { THAILAND: } 1990 \text { TO } 2011\end{array}$ \\
\hline 13.27 & Li, B. and Zhang, J. & $\begin{array}{l}\text { GOVERNMENT DEBT IN AN INTERGENERATIONAL } \\
\text { MODEL OF ECONOMIC GROWTH, ENDOGENOUS } \\
\text { FERTILITY, AND ELASTIC LABOR WITH AN } \\
\text { APPLICATION TO JAPAN }\end{array}$ \\
\hline 13.28 & Robitaille, M. and Chatterjee, I. & $\begin{array}{l}\text { SEX-SELECTIVE ABORTIONS AND INFANT } \\
\text { MORTALITY IN INDIA: THE ROLE OF PARENTS' } \\
\text { STATED SON PREFERENCE }\end{array}$ \\
\hline 13.29 & Ezzati, P. & $\begin{array}{l}\text { ANALYSIS OF VOLATILITY SPILLOVER EFFECTS: } \\
\text { TWO-STAGE PROCEDURE BASED ON A MODIFIED } \\
\text { GARCH-M }\end{array}$ \\
\hline 13.30 & Robertson, P. E. & $\begin{array}{l}\text { DOES A FREE MARKET ECONOMY MAKE AUSTRALIA } \\
\text { MORE OR LESS SECURE IN A GLOBALISED WORLD? }\end{array}$ \\
\hline 13.31 & $\begin{array}{l}\text { Das, S., Ghate, C. and } \\
\text { Robertson, P. E. }\end{array}$ & $\begin{array}{l}\text { REMOTENESS AND UNBALANCED GROWTH: } \\
\text { UNDERSTANDING DIVERGENCE ACROSS INDIAN } \\
\text { DISTRICTS }\end{array}$ \\
\hline 13.32 & Robertson, P.E. and Sin, A. & $\begin{array}{l}\text { MEASURING HARD POWER: CHINA'S ECONOMIC } \\
\text { GROWTH AND MILITARY CAPACITY }\end{array}$ \\
\hline 13.33 & Wu, Y. & $\begin{array}{l}\text { TRENDS AND PROSPECTS FOR THE RENEWABLE } \\
\text { ENERGY SECTOR IN THE EAS REGION }\end{array}$ \\
\hline 13.34 & $\begin{array}{l}\text { Yang, S., Zhao, D., Wu, Y. and } \\
\text { Fan, J. }\end{array}$ & $\begin{array}{l}\text { REGIONAL VARIATION IN CARBON EMISSION AND ITS } \\
\text { DRIVING FORCES IN CHINA: AN INDEX } \\
\text { DECOMPOSITION ANALYSIS }\end{array}$ \\
\hline
\end{tabular}




\section{ECONOMICS DISCUSSION PAPERS}

2014

\begin{tabular}{|c|c|c|}
\hline $\begin{array}{l}\text { DP } \\
\text { NUMBER }\end{array}$ & AUTHORS & TITLE \\
\hline 14.01 & $\begin{array}{l}\text { Boediono, Vice President of the Republic } \\
\text { of Indonesia }\end{array}$ & $\begin{array}{l}\text { THE CHALLENGES OF POLICY MAKING IN A } \\
\text { YOUNG DEMOCRACY: THE CASE OF INDONESIA } \\
\text { (52ND SHANN MEMORIAL LECTURE, 2013) }\end{array}$ \\
\hline 14.02 & Metaxas, P.E. and Weber, E.J. & $\begin{array}{l}\text { AN AUSTRALIAN CONTRIBUTION TO } \\
\text { INTERNATIONAL TRADE THEORY: THE } \\
\text { DEPENDENT ECONOMY MODEL }\end{array}$ \\
\hline 14.03 & Fan, J., Zhao, D., Wu, Y. and Wei, J. & $\begin{array}{l}\text { CARBON PRICING AND ELECTRICITY MARKET } \\
\text { REFORMS IN CHINA }\end{array}$ \\
\hline 14.04 & McLure, M. & $\begin{array}{l}\text { A.C. PIGOU’S MEMBERSHIP OF THE } \\
\text { ‘CHAMBERLAIN-BRADBURY’ COMMITTEE. } \\
\text { PART I: THE HISTORICAL CONTEXT }\end{array}$ \\
\hline 14.05 & McLure, M. & $\begin{array}{l}\text { A.C. PIGOU'S MEMBERSHIP OF THE } \\
\text { 'CHAMBERLAIN-BRADBURY’ COMMITTEE. } \\
\text { PART II: 'TRANSITIONAL' AND ‘ONGOING' ISSUES }\end{array}$ \\
\hline 14.06 & King, J.E. and McLure, M. & HISTORY OF THE CONCEPT OF VALUE \\
\hline 14.07 & Williams, A. & $\begin{array}{l}\text { A GLOBAL INDEX OF INFORMATION AND } \\
\text { POLITICAL TRANSPARENCY }\end{array}$ \\
\hline 14.08 & Knight, K. & $\begin{array}{l}\text { A.C. PIGOU'S THE THEORY OF UNEMPLOYMENT } \\
\text { AND ITS CORRIGENDA: THE LETTERS OF } \\
\text { MAURICE ALLEN, ARTHUR L. BOWLEY, RICHARD } \\
\text { KAHN AND DENNIS ROBERTSON }\end{array}$ \\
\hline 14.09 & Cheong, T.S. and Wu, Y. & $\begin{array}{l}\text { THE IMPACTS OF STRUCTURAL RANSFORMATION } \\
\text { AND INDUSTRIAL UPGRADING ON REGIONAL } \\
\text { INEQUALITY IN CHINA }\end{array}$ \\
\hline 14.10 & $\begin{array}{l}\text { Chowdhury, M.H., Dewan, M.N.A., } \\
\text { Quaddus, M., Naude, M. and } \\
\text { Siddique, A. }\end{array}$ & $\begin{array}{l}\text { GENDER EQUALITY AND SUSTAINABLE } \\
\text { DEVELOPMENT WITH A FOCUS ON THE COASTAL } \\
\text { FISHING COMMUNITY OF BANGLADESH }\end{array}$ \\
\hline 14.11 & Bon, J. & $\begin{array}{l}\text { UWA DISCUSSION PAPERS IN ECONOMICS: THE } \\
\text { FIRST } 750\end{array}$ \\
\hline 14.12 & Finlay, K. and Magnusson, L.M. & $\begin{array}{l}\text { BOOTSTRAP METHODS FOR INFERENCE WITH } \\
\text { CLUSTER-SAMPLE IV MODELS }\end{array}$ \\
\hline 14.13 & Chen, A. and Groenewold, N. & $\begin{array}{l}\text { THE EFFECTS OF MACROECONOMIC SHOCKS ON } \\
\text { THE DISTRIBUTION OF PROVINCIAL OUTPUT IN } \\
\text { CHINA: ESTIMATES FROM A RESTRICTED VAR } \\
\text { MODEL }\end{array}$ \\
\hline 14.14 & Hartley, P.R. and Medlock III, K.B. & $\begin{array}{l}\text { THE VALLEY OF DEATH FOR NEW ENERGY } \\
\text { TECHNOLOGIES }\end{array}$ \\
\hline 14.15 & $\begin{array}{l}\text { Hartley, P.R., Medlock III, K.B., } \\
\text { Temzelides, T. and Zhang, X. }\end{array}$ & $\begin{array}{l}\text { LOCAL EMPLOYMENT IMPACT FROM COMPETING } \\
\text { ENERGY SOURCES: SHALE GAS VERSUS WIND } \\
\text { GENERATION IN TEXAS }\end{array}$ \\
\hline 14.16 & Tyers, R. and Zhang, Y. & $\begin{array}{l}\text { SHORT RUN EFFECTS OF THE ECONOMIC REFORM } \\
\text { AGENDA }\end{array}$ \\
\hline 14.17 & Clements, K.W., Si, J. and Simpson, T. & UNDERSTANDING NEW RESOURCE PROJECTS \\
\hline 14.18 & Tyers, R. & $\begin{array}{l}\text { SERVICE OLIGOPOLIES AND AUSTRALIA'S } \\
\text { ECONOMY-WIDE PERFORMANCE }\end{array}$ \\
\hline 14.19 & Tyers, R. and Zhang, Y. & $\begin{array}{l}\text { REAL EXCHANGE RATE DETERMINATION AND } \\
\text { THE CHINA PUZZLE }\end{array}$ \\
\hline
\end{tabular}




\begin{tabular}{|c|c|c|}
\hline \multicolumn{3}{|c|}{$\begin{array}{l}\text { ECONOMICS DISCUSSION PAPERS } \\
2014\end{array}$} \\
\hline $\begin{array}{l}\text { DP } \\
\text { NUMBER }\end{array}$ & AUTHORS & TITLE \\
\hline 14.20 & Ingram, S.R. & $\begin{array}{l}\text { COMMODITY PRICE CHANGES ARE } \\
\text { CONCENTRATED AT THE END OF THE CYCLE }\end{array}$ \\
\hline 14.21 & Cheong, T.S. and Wu, Y. & $\begin{array}{l}\text { CHINA'S INDUSTRIAL OUTPUT: A COUNTY-LEVEL } \\
\text { STUDY USING A NEW FRAMEWORK OF } \\
\text { DISTRIBUTION DYNAMICS ANALYSIS }\end{array}$ \\
\hline 14.22 & $\begin{array}{l}\text { Siddique, M.A.B., Wibowo, H. and } \\
\text { Wu, Y. }\end{array}$ & $\begin{array}{l}\text { FISCAL DECENTRALISATION AND INEQUALITY IN } \\
\text { INDONESIA: 1999-2008 }\end{array}$ \\
\hline 14.23 & Tyers, R. & $\begin{array}{l}\text { ASYMMETRY IN BOOM-BUST SHOCKS: } \\
\text { AUSTRALIAN PERFORMANCE WITH OLIGOPOLY }\end{array}$ \\
\hline 14.24 & Arora, V., Tyers, R. and Zhang, Y. & $\begin{array}{l}\text { RECONSTRUCTING THE SAVINGS GLUT: THE } \\
\text { GLOBAL IMPLICATIONS OF ASIAN EXCESS } \\
\text { SAVING }\end{array}$ \\
\hline 14.25 & Tyers, R. & $\begin{array}{l}\text { INTERNATIONAL EFFECTS OF CHINA'S RISE AND } \\
\text { TRANSITION: NEOCLASSICAL AND KEYNESIAN } \\
\text { PERSPECTIVES }\end{array}$ \\
\hline 14.26 & Milton, S. and Siddique, M.A.B. & $\begin{array}{l}\text { TRADE CREATION AND DIVERSION UNDER THE } \\
\text { THAILAND-AUSTRALIA FREE TRADE AGREEMENT } \\
\text { (TAFTA) }\end{array}$ \\
\hline 14.27 & Clements, K.W. and Li, L. & VALUING RESOURCE INVESTMENTS \\
\hline 14.28 & Tyers, R. & $\begin{array}{l}\text { PESSIMISM SHOCKS IN A MODEL OF GLOBAL } \\
\text { MACROECONOMIC INTERDEPENDENCE }\end{array}$ \\
\hline 14.29 & Iqbal, K. and Siddique, M.A.B. & $\begin{array}{l}\text { THE IMPACT OF CLIMATE CHANGE ON } \\
\text { AGRICULTURAL PRODUCTIVITY: EVIDENCE } \\
\text { FROM PANEL DATA OF BANGLADESH }\end{array}$ \\
\hline 14.30 & Ezzati, P. & $\begin{array}{l}\text { MONETARY POLICY RESPONSES TO FOREIGN } \\
\text { FINANCIAL MARKET SHOCKS: APPLICATION OF A } \\
\text { MODIFIED OPEN-ECONOMY TAYLOR RULE }\end{array}$ \\
\hline 14.31 & Tang, S.H.K. and Leung, C.K.Y. & $\begin{array}{l}\text { THE DEEP HISTORICAL ROOTS OF } \\
\text { MACROECONOMIC VOLATILITY }\end{array}$ \\
\hline 14.32 & Arthmar, R. and McLure, M. & $\begin{array}{l}\text { PIGOU, DEL VECCHIO AND SRAFFA: THE } 1955 \\
\text { INTERNATIONAL ‘ANTONIO FELTRINELLI’ PRIZE } \\
\text { FOR THE ECONOMIC AND SOCIAL SCIENCES }\end{array}$ \\
\hline 14.33 & McLure, M. & $\begin{array}{l}\text { A-HISTORIAL ECONOMIC DYNAMICS: A BOOK } \\
\text { REVIEW }\end{array}$ \\
\hline 14.34 & Clements, K.W. and Gao, G. & $\begin{array}{l}\text { THE ROTTERDAM DEMAND MODEL HALF A } \\
\text { CENTURY ON }\end{array}$ \\
\hline
\end{tabular}




\begin{tabular}{|c|c|c|}
\hline \multicolumn{3}{|c|}{$\begin{array}{l}\text { ECONOMICS DISCUSSION PAPERS } \\
2015\end{array}$} \\
\hline $\begin{array}{l}\text { DP } \\
\text { NUMBER }\end{array}$ & AUTHORS & TITLE \\
\hline 15.01 & Robertson, P.E. and Robitaille, M.C. & $\begin{array}{l}\text { THE GRAVITY OF RESOURCES AND THE } \\
\text { TYRANNY OF DISTANCE }\end{array}$ \\
\hline 15.02 & Tyers, R. & $\begin{array}{l}\text { FINANCIAL INTEGRATION AND CHINA'S GLOBAL } \\
\text { IMPACT }\end{array}$ \\
\hline 15.03 & Clements, K.W. and Si, J. & $\begin{array}{l}\text { MORE ON THE PRICE-RESPONSIVENESS OF FOOD } \\
\text { CONSUMPTION }\end{array}$ \\
\hline 15.04 & Tang, S.H.K. & $\begin{array}{l}\text { PARENTS, MIGRANT DOMESTIC WORKERS, AND } \\
\text { CHILDREN’S SPEAKING OF A SECOND } \\
\text { LANGUAGE: EVIDENCE FROM HONG KONG }\end{array}$ \\
\hline 15.05 & Tyers, R. & $\begin{array}{l}\text { CHINA AND GLOBAL MACROECONOMIC } \\
\text { INTERDEPENDENCE }\end{array}$ \\
\hline 15.06 & $\begin{array}{l}\text { Fan, J., Wu, Y., Guo, X., Zhao, D. and } \\
\text { Marinova, D. }\end{array}$ & $\begin{array}{l}\text { REGIONAL DISPARITY OF EMBEDDED CARBON } \\
\text { FOOTPRINT AND ITS SOURCES IN CHINA: A } \\
\text { CONSUMPTION PERSPECTIVE }\end{array}$ \\
\hline 15.07 & $\begin{array}{l}\text { Fan, J., Wang, S., Wu, Y., Li, J. and Zhao, } \\
\text { D. }\end{array}$ & $\begin{array}{l}\text { BUFFER EFFECT AND PRICE EFFECT OF A } \\
\text { PERSONAL CARBON TRADING SCHEME }\end{array}$ \\
\hline 15.08 & Neill, K. & $\begin{array}{l}\text { WESTERN AUSTRALIA'S DOMESTIC GAS } \\
\text { RESERVATION POLICY THE ELEMENTAL } \\
\text { ECONOMICS }\end{array}$ \\
\hline 15.09 & Collins, J., Baer, B. and Weber, E.J. & $\begin{array}{l}\text { THE EVOLUTIONARY FOUNDATIONS OF } \\
\text { ECONOMICS }\end{array}$ \\
\hline 15.10 & $\begin{array}{l}\text { Siddique, A., Selvanathan, E. A. and } \\
\text { Selvanathan, S. }\end{array}$ & $\begin{array}{l}\text { THE IMPACT OF EXTERNAL DEBT ON ECONOMIC } \\
\text { GROWTH: EMPIRICAL EVIDENCE FROM HIGHLY } \\
\text { INDEBTED POOR COUNTRIES }\end{array}$ \\
\hline 15.11 & Wu, Y. & $\begin{array}{l}\text { LOCAL GOVERNMENT DEBT AND ECONOMIC } \\
\text { GROWTH IN CHINA }\end{array}$ \\
\hline 15.12 & Tyers, R. and Bain, I. & $\begin{array}{l}\text { THE GLOBAL ECONOMIC IMPLICATIONS OF } \\
\text { FREER SKILLED MIGRATION }\end{array}$ \\
\hline 15.13 & Chen, A. and Groenewold, N. & $\begin{array}{l}\text { AN INCREASE IN THE RETIREMENT AGE IN CHINA: } \\
\text { THE REGIONAL ECONOMIC EFFECTS }\end{array}$ \\
\hline
\end{tabular}

